\title{
Conservation Conjunctures: Contestation and Situated Consent in Peru's Huascarán National Park
}

\author{
Mattias Borg Rasmussen ${ }^{\mathrm{a}, \#}$, Adam French ${ }^{\mathrm{b}}$, and Susan Conlon ${ }^{\mathrm{c}}$ \\ ${ }^{a}$ Department of Food and Resource Economics, University of Copenhagen, Frederiksberg, Denmark \\ ${ }^{b}$ Risk and Resilience and Advanced Systems Analysis Programs, International Institute for Applied Systems Analysis (IIASA), \\ Laxenburg, Austria \\ 'School of International Development and Water Security Research Centre, University of East Anglia, Norwich, UK
}

\#Corresponding author. E-mail: mbr@ifro.ku.dk

\begin{abstract}
When the Huascarán National Park in the Peruvian highlands was established in 1975, consultation with the local comundidades campesinas (peasant communities) was limited. While no consent was sought or given, prior to park establishment, post-facto attempts to include the surrounding communities in the conservation efforts have produced diverse responses from the local population. This paper reviews the history of this process by discussing three distinct cases in which the Huascarán National Park has devised strategies for negotiating the legitimacy of its control over park resources with neighbouring comunidades campesinas. In examining these park-community dynamics from the standpoint of control over the aesthetic and productive values of natural resources and territory, the article explores the emergence of authority and the exercise of power in conservation. We argue that within the Huascarán National Park, different modalities of governance exist partially and simultaneously, and that conservation conjunctures are historically conditioned sedimentations that continuously shape the park-people relationship. This leads the park to appear as both a paper park and fortress-style conservation entity in different sites and moments. The paper highlights the problem of creating consent post facto in defining the use of landscapes, thereby underscoring the importance of a grounded and historically specific analysis of attempts to create social inclusion in processes framed as development.
\end{abstract}

Keywords: Andes, Peru, Territory, Legitimacy, Authority, Resource control

\section{INTRODUCTION}

Conservation encounters produce particular relations between people and the environment, often transforming existing territorial dynamics (West et al. 2006). In diverse contexts, conservation initiatives such as the establishment of protected areas have led to tensions over resource access and control (Adams and Hutton 2007). These dynamics frequently involve

\begin{tabular}{|l|l|}
\hline \multicolumn{2}{|c|}{ Access this article online } \\
\hline Quick Response Code: & Website: \\
\hline & www.conservationandsociety.org \\
\cline { 2 - 3 } & \\
\hline
\end{tabular}

contestation and conflict over territorial authority between actors with differing sociocultural values and material demands on the resource base in question. These interactions, in turn, are contingent upon social and political processes and often change over time as power balances shift and values and paradigms evolve.

Trends in conservation have found new ways of framing both the relationship between parks and people, and people and environment, moving from top-down to participatory forms of management. Behind such processes are deep concerns about the legitimacy of resource control and the question of how authority is established within territorial jurisdictions. Legitimacy is a site of encounters, an arena of contestation over who has the right to govern particular resources, territories, or people (Jeffrey et al. 2015). A number of studies have been concerned with the role of legitimacy in natural resource

Copyright: (C) Rasmussen et al 2018. This is an open access article distributed under the terms of the Creative Commons Attribution License, which permits unrestricted use and distribution of the article, provided the original work is cited. Published by Wolters Kluwer - Medknow, Mumbai | Managed by the Ashoka Trust for Research in Ecology and the Environment (ATREE), Bangalore. For reprints contact: reprints@medknow.com 


\section{2 / Rasmussen et al.}

governance, linking it to knowledge (Brockington and Scholfield 2010; Leino and Peltomaa 2012), empowerment (Baral and Stern 2010; Paloniemi and Vainio 2011), coercion (Rantala et al. 2013), and trust (Stern and Coleman 2015). All these approaches focus on the shifting relations between the governed and those who claim the right to govern.

In this paper, we examine the complex and shifting dynamics of legitimation produced by conservation encounters between the state managers of Peru's Huascarán National Park (henceforth the Park) and neighbouring resource users. Our point of departure is that conservation practices - and broader livelihood pursuits - are historically contingent, that is, conjunctural and marked by the structural conditions of possibility. Among other things, conjunctures entail economics, politics, and policies, as well as the material qualities of local geographies and social boundaries. Critically for our concerns, they also include plural legal and normative institutional arrangements with varying degrees of definition, legitimacy, and robustness.

When the Park-home to the highest peaks in the tropical Andes and one of Peru's flagship protected areas was established in 1975 in the wake of the 1969 agrarian reform and a devastating earthquake in 1970, consultation with local comunidades campesinas (peasant communities) was limited (Barker 1980; Lipton 2014). We are interested in how the historical trajectory of park establishment and development in conjunction with broader regional dynamics has shaped interactions between state authorities and the comunidades campesinas whose livelihoods incorporate resources and territory within the park boundary. The analysis is concerned particularly with specific processes by which the park's conservation agenda has been continuously legitimised. Here, park staff and local residents negotiate both informal understandings and formal agreements to move beyond resource conflicts and allow the coexistence of competing land uses and claims to authority. We stress the role of resources vital to livelihood production, and in particular on revenues from tourism, and how authority and territorial jurisdictions are negotiated through contractual relations related to links between conservation and local livelihoods.

By highlighting the diverse engagements and fragmented territoriality of the Park and its spatio-temporal variations, we suggest that one seemingly singular protected area can simultaneously display characteristics of both a fortress (Brockington 2002) and a paper park (Blackman et al. 2015) with elements of community-based conservation (Goldman 2003; Nelson and Agrawal 2008) and landscape conservation (McCall 2016) enforced in different ways and to differing degrees across its territory. While a fortress conservation model works through the dispossession of land and livelihoods, a paper park exists mostly in maps and policy documents, with little actual impact on landscapes and everyday lives. We argue that in the Park, neither model exists in archetypical form. By conceptualising grounded conservation outcomes as processes of negotiated legitimation rather than park-types with an ontological status in and of themselves, we show how the dynamics between the park and neighbouring communities continuously shape the existing modalities of governance, leading to variations in the enforcement of borders and policies within the same institutional structure. By showing how specific claims to resources-e.g. tourism revenues, highland pastures, or irrigation water-generate specific social relations, we suggest that struggles over resource control can reveal the situatedness of conservation legitimacy and explain why Andean farmers may, both support the conservation project at large and yet adamantly contest particular conservation measures and policies. In so doing, we underscore that the legitimacy of conservation efforts in such cases of shared resources will often be fragile and precarious achievements.

Ideal types of conservation lend themselves well to comparisons but prevent us from seeing the contradictions and processes of change embedded in their formulation. To the contrary, the cases we unpack below show how the governance of a park is not the outcome of a single wilful design, but instead is a process of continuous negotiations, which include strategic alignments, contestation and processes of legitimation. Our basic proposition is therefore both methodological and empirical. We do not wish to dismiss comparison as such but rescale comparison by emphasising park governance as process (Moore 2005). We suggest focusing on three domains in the ongoing contestations over resource control-1) the materiality of the resource, 2) the historical conditions of resource control, and 3) the concrete modalities of governance. Combined, these features reveal the situatedness of legitimacy in conservation encounters.

To understand the intersections between the park's conservation paradigm, its legitimation, and the continued pursuit of local livelihoods, we chronicle the park management's attempts, post facto, to create consent for conservation as a key component of regional development. Rather than understanding 'development' as something solely external to and imposed upon local contexts, however, we highlight the adeptness of rural communities at negotiating spaces for the continuation and evolution of local livelihoods within development processes (cf. Bebbington 2000). Through its enduring conservation agenda, the park has reinforced particular visions of development and land use, ensuring activities such as mining are not established while tourism in its various guises has emerged as the option most compatible with conservation. As we detail below, we do not detect a pattern where existence of park personnel and projects inevitably lead to resistance and community mobilisation. Rather, successful conservation encounters are conditioned by the meaningful articulations between such projects, local livelihoods, community politics, conservation agendas, and everyday interactions.

\section{METHODS: UNRAVELLING CONSERVATION ENCOUNTERS}

We examine how community characteristics and local historical trajectories have influenced relationships with the park and its 
two pillars, conservation and tourism, in three distinct cases. Our examples suggest the diversity of engagements that the park has with its approximately 50 adjacent communities, where different ecological zones and community priorities create varied combinations of livelihood strategies. Existing for more than forty years in these diverse contexts, the Park has renegotiated its presence as a public institution in dynamic relation to longstanding but shifting local claims to resource use and territorial control. We develop our argument by reviewing the remarkably different relations between the park and three of its neighbouring comunidades campesinas (henceforth CC when prefix): CC Cruz de Mayo and CC Unidos Venceremos in the northwestern part of the park, and CC Catac in its southwestern reaches (see Figure 1) ${ }^{1}$.

Rather than the outcome of a single coherent project, this article is based on each author's separate fieldwork, together embodying more than 50 months of ethnographic engagement with local communities and park officials. These engagements included participant observation at meetings, working parties, and encounters between park administration and community leaders, as well as interviews with park personnel and with

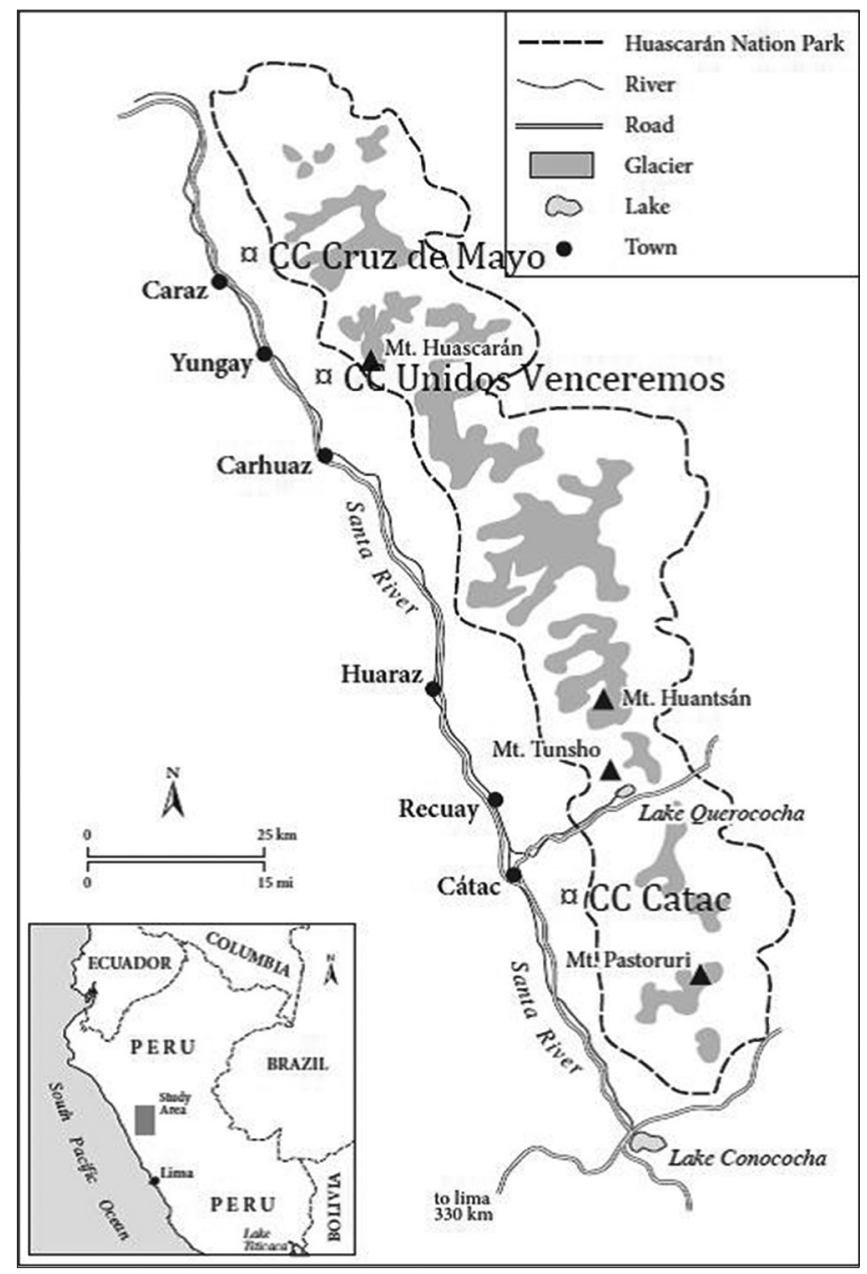

Figure 1

Map of the Huascarán National Park with the location of the three case studies. Source: Rasmussen (2015), modified both ordinary members and the changing leadership of the three communities. We have also each analysed policy documents, community documents, and park-community contracts. Through conversations after the ethnographic fact, we found that the juxtaposition of our three sites and their historical relationship to the park administration produce insights on park-people dynamics that none of the cases would achieve independently. From each site we have selected key events and dynamics that have shaped the contemporary relationship between the comunidades campesinas and the park. We also describe the mundane quasi-events that become part of the everyday interactions between peasants working to sustain and improve livelihoods in a challenging biophysical and socio-political environment, and park personnel seeking to enhance positive conservation outcomes in a complicated social terrain. The analysis reveals the topological unevenness of both community priorities and park presence.

\section{ANALYTICAL PERSPECTIVES: CONJUNCTURE AND LEGITIMACY}

Conservation conjunctures are constituted at the interface between global trends, conservation policies and local contexts. At this interface, local histories, memories, landscapes, and power struggles meet travelling ideas and forms of knowledge. Such interfaces create friction, an awkward coexistence of social and political projects (Tsing 2005), which shapes conservation outcomes. Conservation encounters thus encompass embedded cultural ideas and contexts that reveal specific ways in which power is lived, produced, and contested (Li 2007). Focusing on such conjunctures, we examine the ways in which conservation influences local livelihoods, affecting how institutions govern and which institutions may do so. We aim to explore the set of specific elements, processes, and relations that shape people's lives and possibilities for development at particular places and times and which may affect the legitimacy of governing institutions. Negotiating fragmented legitimacies is therefore a process that involves the rearrangement of the relationship between resources, people, and governing institutions. Such relations - or social contracts - involve mutual recognition of the parties involved (Lund 2016). Enduring negotiations over legitimacy invite us to explore, first, what kinds of social contract are possible between a park management that is mainly upwardly accountable - at least officially - and communities, which may resist and support different aspects of conservation objectives. Second, we ask what kinds of alternative socio-political arrangements may be invoked by non-sovereign actors - such as the national park and the comunidades campesinas - in order to secure control over space and resources and how these efforts are legitimised vis-à-vis the counterpart.

Conservation conjunctures combine attention to the legitimation of resource control and its distribution to the factors that enable such arrangements. Hegemony as it relates to political ecology (Ekers et al. 2009) connects to our concern with legitimacy in that it provides a vocabulary for 


\section{4 / Rasmussen et al.}

understanding why and how people consent to and participate in social relations that are fundamentally unjust. However, the cases we discuss reveal the incompleteness of hegemony in conservation encounters marked by the awkward coexistence and situated alignments of contradictory territorial projects. Consequently, in our analysis we stick to legitimation in order to pinpoint the spatio-temporal specificities and openendedness of these processes of consent. We are inspired by recent works on the specificities of institutional dynamics which shape resource control and access, thereby suggesting that nature is a key locus of state power and legitimacy (Asher and Ojeda 2009; Yeh 2012; Li 2014, 2016). Conjunctural analysis fundamentally historicises such dynamics (Li 2016), revealing how constellations of power operate across nested scales connecting the site-specific to the general. These insights structure our analysis in two key ways - first, we ground the analysis in critical events that have been made possible by particular conjunctures, and second, we unpack those conditions of possibility with particular attention to the ways in which they are shaped by processes of legitimation.

Legitimacy is conjunctural. What is legitimate varies across time and space, but always involves conflict and negotiation over the authority to define resource access and distribution. Authority does not exist prior to territorial control but emerges as a product of the ability to control (Sikor and Lund 2009). A central feature of such processes is that of legitimation, that is, how the institutional control over resources and space is legitimised. Even universalised principles true in every country as expressed through law depend on legitimation by which they become 'naturalized' (Mitchell 2002). Concomitantly, it follows from key insights in legal anthropology that law-making and the institutionalisation of resource control is a processual and historically contingent process (Moore 2000). As David Mosse has acutely observed, legitimation creates coherent accounts of policy interventions and undergirds authority, even post hoc (Mosse 2004). In that regard, Sikor and Lund point to how negotiations over legitimacy involve the work of concepts or 'truths' that may define the reach of political projects, thus conditioning what can be claimed upon which grounds.

Legitimacy is linked to the constitution of authority through the exercise of power. Weber (1968) identifies a crucial link between compliance and legitimation: it is exactly through compliance that power is legitimated and becomes authority. While Weber stressed the predisposition of persons to obey legitimate authority, regardless of the basis upon which such belief is established (Colfer 2011), we emphasise that we are concerned with what Connelly et al. (2006) have termed 'situated legitimacy'. This notion suggests that legitimacy is a rather unstable socio-political process that requires constant care and negotiation (see also Leino and Peltomaa 2012). Legitimising practices work in a grey zone where not all forms of power determining who has access to what are seen as equally legitimate (Sikor and Lund 2009). Institutional frameworks do not precede legitimate rule (Cleaver and De Koning 2015; Lund 2016) and local communities are often engaged in 'forum shopping' between different normative frameworks (von Benda-Beckmann 1981). These institutional frameworks may derive their legitimate authority from cultural frameworks (adat, in the case of West Sumatra; uso $y$ costumbres in a broader sense as understood in the Andes), legal frameworks, or jurisdictions. In other words, the social contract of legitimate authority and resource control involves a mutual recognition by the parties involved, and it is therefore crucial to understand how such legitimations are brought forward and sustained.

The relationship between the park and neighbouring communities is influenced by overlapping legislative frameworks (Law of Comunidades Campesinas, Ley no. 24656, Law of Protected Areas, Ley no. 26834), international organisations and agreements (International Union for the Conservation of Nature (IUCN), UNESCO's World Heritage Convention, International Labour Organization (ILO) and in particular their Convention 169 ratified by Peru in 1994, UNEP and the Biodiversity Convention of 1992), and situated understandings of power, legitimacy, and authority. Below, we document the different constellations of forces and interests that produce or contest legitimate resource control in our community case studies. We detail the variations of legitimacy over time and between the three cases, emphasising the different strategies for negotiating control over resources linked to particular communities.

\section{CONTEXT: HUASCARÁN NATIONAL PARK AND ITS NEIGHBOURING COMMUNITIES}

The Park was established in 1975 to conserve 340,000 hectares of the Andean highlands of north-central Peru (Decreto Supremo No. 0622-75-AG). The park encompasses most of the Cordillera Blanca, the world's highest and most extensively glaciated tropical mountain range, an important reserve of freshwater and high-altitude biodiversity, and a global destination for trekking and mountaineering (Young and Rodriguez 2006). The park was designated a UNESCO Biosphere Reserve in 1977 and recognised as a UNESCO World Heritage Site in 1985. It extends roughly $180 \mathrm{~km}$ from north to south and $40 \mathrm{~km}$ from west to east and is bounded on the west by the Callejón de Huaylas - the broad alluvial valley of the upper Santa River - and on the east by the less-populated valley of the Callejón de Conchucos. The park and its surroundings have a long history of human land use as illustrated by numerous pre-Incan archaeological sites, the pre-conquest salt and coca trade, colonial mineral extraction and wool production, and present-day development (Thorp and Bertram 1978, Raimondi 2006 [1873], Carey 2010). Park administration is based in the city of Huaraz (approx. 120.000 inhabitants), the largest city in the Callejón de Huaylas and the capital of the Department of Ancash. Below we detail the territorial and institutional development of the park in its relation to the surrounding communities and livelihoods and show how simultaneous modalities of conservation governance shape conservation practices. 
Many of the communities bordering the Park share the formal status currently recognised under the 1987 Law of Comunidades Campesinas (Ley no. 24656). More than 6,000 comunidades campesinas exist across the highlands of Peru, generally organised around the administration of communal lands and social relations (Diez 2012). Being recognised as a comunidad campesina does not lead automatically to collective ownership of land, and in many instances comuneros (members of a comunidad campesina) have engaged in struggles that extend over decades to secure what they perceive to be their land rights. The agrarian reform process, which was initiated in 1969 (Mayer 2009), facilitated the delineation and establishment of the park through its reconfigurations of land ownership, but also contributed to enduring disputes over territorial control and institutional legitimacy ${ }^{2}$. The Park was thereby inserted into an unstable territorial terrain, where the current distribution of lands reflects former distribution patterns rather than pre-given territorial units. Along with the establishment of the agrarian cooperative enterprises (Sociedad Agraria de Interés Social, SAIS), the park therefore emerged as a territorialising agent imposed by the central government with little legitimacy to claim resource control in a context where many rural dwellers viewed territories as their historical right.

From the outset, the creation of the Park was seen as a means to spur increased tourism and economic development in the region, while contributing to the conservation of emblematic Andean species and landscapes (Barker 1980). This, however, was the vision held by regional politicians and businesspeople and shared by international mountaineers but hardly embraced by the local peasant populations. Their livelihoods depended on the conservation of resources to be carried out by a park that conceptually they little understood (Lipton 2014). As a result, processes of negotiation with local residents began even before the park's formal establishment, and in 1974, 91 properties (83 of which corresponded to "community or peasant enterprises") were involved in negotiations related to park boundaries that entailed compensation for land expropriation through "money, bonds, or future employment in the park" (Barker 1980: 16). Despite such processes, interviews undertaken several decades later with respondents in various reaches of the park's buffer zone reported that many local populations were never informed of the park boundaries and that most respondents still consider the resources within the Park as "the legal property of the peripheral park communities" (Lipton 2014: 829). While, to our knowledge, no violence was employed, a number of legal and discursive operations effectively fenced off parts of former usufruct territories, spatially separating people and landscapes.

Throughout most of the Park, the official boundary was established at the 4,000 m contour, which was considered the approximate upper limit of cultivation (Barker 1980). Within the park boundary, land-use corresponds to five distinct use zones with varying levels of restrictions on human activity (HNP 2003). While the original decree establishing the park stated that some "traditional" resource uses as well as existing mining activities ${ }^{3}$ could continue, livestock grazing was prohibited. Nevertheless, given the widespread dependence of local residents on pastures within the park, this prohibition was relaxed on an "experimental basis," (Barker 1980: 17) with the hope that employment from a growing tourism sector would lead to less grazing pressure on the park's pastures over time. Many residents continue to graze animals on park territory today (Lipton 2014) and impacts from overgrazing are a significant concern for both park staff and agro-pastoralists themselves who have witnessed declines in the quality of pasturage (Bury et al. 2011). Fariss (2007, especially chapter 3) points to a number of adverse effects of tourism on local communities, which range from the uneven allocation of tourism revenue to impacts on household decision-making and livestock rearing that have refocused labour inputs and exacerbated patterns of overgrazing by restructuring herd composition. In addition to grazing, many local residents collect medicinal or useful plants from the park (Lipton 2014). While these activities undoubtedly impact the environment in ways that contradict the park's formal regulations and conservation mission, the long history of local dependence on and productive use of these highland landscapes continues to be permitted and their curtailment would likely generate significant social resistance. The increasing emphasis on zoning in park management that extends conservation priorities beyond the park nucleus further suggests that conservation in the Park is conceived as a landscape-level project rather than a strategy targeted at specific species.

The widespread, meaningful participation of local residents in park governance is an enduring challenge, and in many parts of the Park's territory, historical park-community relations have been divisive (Lipton 2014). In the mid-1990s, with assistance from the international Non-Governmental Organisation (NGO) The Mountain Institute, the park administration created a tourism management plan for the park that included participatory processes involving at least some representatives of neighbouring "indigenous communities" (Torres 1996). This process predated the most recent Law of Protected Areas (Ley no. 26834 implemented by Decreto Supremo no. 038-2001-AG), which underscores the importance of local participation (although without discussing specific instruments by which to accomplish it). ${ }^{4}$ A second participatory process for developing the 2003-2007 Huascarán National Park management plan was facilitated by The Mountain Institute in 2002 and involved representatives from a number of communities neighbouring the park (HNP 2003). These participants were in most cases representatives of two community-level institutions designed to govern local use of the park's resources and facilitate park-community relations - the ASAAMs (Asociación de Servicios de Auxilio de Alta Montaña, Association of High Mountain Auxiliary Services) and the CUPs (Comité de Usuarios de Pastos, Pasture Users' Committees) (HNP 2003). Both institutions are direct outcomes of the park's presence in the area. Notably, few people in the comunidades campesinas where we worked had been involved in the previous plan's elaboration, and no one interviewed had seen the current park 


\section{6 / Rasmussen et al.}

management plan. Such partial or merely nominal inclusion may undermine park legitimacy.

It is a constant challenge to embrace both tourism and conservation in the Cordillera Blanca region (Grötzbach 2003: 132). Although tourism was envisioned as a common pursuit for communities, the regional industry has developed in a way that has favoured particular locations close to the park's most popular sites and access points. Huaraz-based agencies also direct most of the tourism market and commonly work with particular groups of trusted service providers in individual communities. As in other protected areas in Peru, the Park has experienced an increase in the number of visitors over recent decades, with particular growth in domestic tourism over the last decade (e.g. from 144,982 visitors in 2007 to 259,090 in 2016). For 2009 and 2014, just above 13 percent of visitors to Peru's protected areas came to Huascarán National Park. According to the Park's own statistics, the great majority of visitors is domestic (from 2007-2009 ranging around 80 percent) and primarily engaged in conventional tourism (from 2007-2009 ranging around 90-95 percent). This is likely to reinforce the value capture of the Huaraz-based agencies since domestic tourists typically take one-day trips while staying and eating in Huaraz. One-day visits also create impetus for small-scale tourist offerings as we see in Pastoruri (CC Catac) and Llanganuco (CC Unidos Venceremos). In 2016, Llanganuco received 96.449 visitors, Pastoruri 56.980. Lake Parón (CC Cruz de Mayo) merely received 2,534 visitors. From January to September that year, $74 \%$ of the visitors to the Park were domestic. ${ }^{5}$

Huascarán National Park is one of Peru's flagship parks, yet it faces perennial challenges related to sufficient funding and personnel to administer its vast and rugged territory. This is reflected in the uneven presence of park rangers across the terrain. Diversity in community-specific characteristics such as levels of social cohesion, institutional capacities, and livelihood strategies between the park's numerous neighbouring communities presents additional challenges for the development of a singular strategy of engagement with the Park and its resources. While the enrolment of local populations in the conservation project might be touted as community-based conservation, we suggest that attention must be paid to how this selection is taking place, the alliances and fissures created by selective inclusion, and the enduring inaction in other places. It is within these dynamics that we detect the emergence and simultaneity of different modalities of conservation governance.

\section{SITUATED LEGITIMACIES}

This section presents data from our three sites - CC Catac, CC Cruz de Mayo, and CC Unidos Venceremos (See Figure 1). The objective here is to highlight the particular conjunctures that created conditions for new forms of interaction between park and community. Each case shows how different conjunctures shape local power constellations as ideas about conservation and community engagement meet new forms of community organisation and resources to be controlled. These conservation conjunctures at the local scale converge with those operating at a more extended political and social scale. Contests over legitimacy emerge as notions of authority, community, and resource control are brought into alignment or collision by these conjunctural pressures. Thus, efforts to legitimise are strategic, sometimes manipulative, and not always successful.

The dramatic features of the landscape in the Cordillera Blanca - its verticality - translate into distinct livelihood portfolios across our sites. Furthermore, we see in all cases substantial off-farm income activities, including occupational migration to nearby mining sites, construction work, or unskilled manual labour in the major cities on the coast. As a result of such diversity as well as individual conflicts with some communities, the park administration has increasingly pursued, or been pressured into, specific engagements with a selection of its neighbours. Among our case study communities, only CC Catac was recognised under the faculties of the 1933 constitution, while both CC Cruz de Mayo and CC Unidos Venceremos were established as comunidades campesinas after the agrarian reform. While comunidades campesinas are autonomous institutions, they overlap and interact to varying degrees with a wide array of other political and territorial government structures (e.g. district and provincial governments) and resource management entities (e.g. irrigator associations and national parks) whose competencies in terms of infrastructure or other rural provisions are not always clearcut. This results in a complex institutional and bureaucratic reality in which comuneros must navigate.

\section{Catac: contested claims to territorial histories}

CC Catac controls a territory of approximately 66,000 ha from Chacaypampa to Mojón de Cajatambo and from the brink of the Santa River to the high peaks of the Cordillera Blanca. Located in the southernmost part of the Park, CC Catac was recognised as a comunidad indigena (later campesina) in 1946 (Resolución Suprema S/N, February 18, 1946, ratified by Resolución Suprema no. 045, June 24, 1957). It is an area dominated by livestock, small-scale farming as well as various more or less permanent salaried occupations either in the town of Catac, in the regional capital of Huaraz an hour away, or on the coast. As of 2015, its membership base was constituted by almost a thousand households. Catac is both a comunidad campesina and the name of a small town, which is also a district with municipal capacities. Historically, these two institutions have competed over the right to define development in the area. Municipal decentralisation and the canon minero, a mining levy, have shifted the balance between municipality and CC Catac, where the 'power to mobilise', as one former president put it, has been challenged by the increased political and economic capacity of the otherwise poor rural municipality. Still, few things happen in Catac without the consent of CC Catac.

Ownership of the territories that make up CC Catac was historically fragmented, but comuneros hold deeply seated 
beliefs about their ancestral right to the land. When the park was established it was read into a context of struggles over land and resources locally referred to as the recuperación de tierras, literally the recovery of lands (Rasmussen 2018a). Alluding to the gradual territorial recovery from a landed elite, in CC Catac questions of resource sovereignty, i.e. who can legitimately control who extracts what for what purpose, are therefore as important as the actual exploitation of the resources. This goes both for the now abolished (officially, at least) mining activities as well as agro-pastoral practices. Roughly $62 \%$ of the territory of CC Catac is located in the park nucleus, the rest in the buffer zone. The comuneros enjoy full usufruct rights to the territories. The park maintains its right to have an opinion on the construction of for example irrigation networks (Rasmussen 2016). Furthermore, actual land ownership is in dispute and the legal office of the park is currently claiming full legal titles for some of the high-altitude territories.

The lack of bank credit is an incentive to maintain livestock herds. According to the park administration, across the territory of the Park, one of the greatest challenges to conservation is the over-exploitation of the pastures. In Catac such ecological concerns, while recognised by individual comuneros, are dwarfed by their quotidian attention to economically sustainable livelihoods (Rasmussen 2018a; Bury et al. 2011). In a context of limited access to formal credit, maintaining a substantial herd (at least 60-80 animals) in the altitudes is a common strategy to secure funds for unexpected expenses. Tensions as to the adequate use of the pasturelands are emerging between the park administration and the $\mathrm{CC}$, but no action has been taken by the former, and the latter do not enforce local restrictions on animals. As a consequence, agro-pastoral livelihoods are only affected by the presence of the park to a limited extent. Practices of burning pastures are abolished, although there may be occasional small-scale burnings, which are then potentially sanctioned by the imposition of fines by park rangers. The internal statute of CC Catac, otherwise highly detailed in it regulations of comuneros - down to putting fines on those throwing candy wrappers on the floor during the general assembly (article 56-5) — has no mentioning of the burning of pastures.

Tensions over resource exploitation writ large are therefore played out differently in different arenas, reflecting community priorities through its organisation in different specialised committees and economic activities. The tourism business has been the site of most encounters between the park and the community. In the 1980s, Pastoruri was a prime site of tourism in Peru. Easily accessible by vehicle, this glacier (altitude 5000-5475 m above sea level in 2009) attracted many visitors - primarily domestic tourists - who increasingly provided an important component of local household incomes. People came together in vendors' organisations to provide three main services to tourists: portage, the hire of horses, and the sale of food ${ }^{6}$. While not formally integral to the community, most communication between the park and the vendor associations came to be mediated by specialised committees or community leadership bodies. Historically, the park has worked to manage such contact, and park employees spent a great deal of effort trying to control and direct the work of these organisations in their formative phase. In more recent years, such contact and management have been replaced by direct mediation through community leadership structures.

The vendors' organisations share work available at the Pastoruri facilities on a strict regime of rotation. Most members of these organisations have ties to the area around Pastoruri, having their own high-altitude dwellings in the same watershed. But Pachacoto is only one of the four watersheds that make up the community territory, and for the majority of comuneros the presence of the park has a more limited impact on their livelihoods. Despite this uneven distribution of park-people contact zones, however, and the relatively low-key enforcement of regulations by the park administration, historically the relationship between the park and the community has been tense. This is due to how individual livelihood strategies of comuneros converge with ideas about the comunidad campesina as a sovereign body with a deep history of settlement and the right to decide its own future. Two cases in particular are worth attention: a lawsuit regarding legal boundaries that has been ongoing since 1997 and a 2001-2007 lawsuit following the blockading of the entrance to Pastoruri on June 24, 2001. The latter involved open confrontations between law enforcement and comuneros when members of CC Catac gathered at the junction between the road connecting Catac to Lima and the gravel road leading to Pastoruri. Charging admission fees at a location just before the official park entrance at Carpa, comuneros signalled that they did not want to see all the revenues from the park going directly to the administrations in Huaraz or Lima. During six years of judicial proceedings, the community continued to charge fees.

While the court in Huaraz ruled in favour of the park in 2007 , the off-court negotiations that followed had two significant results. First, the leaders responsible for the blockade did not have to go to jail. And second, the terms of the contract signed on October 9, 2009 now stipulated that the income from park fees be divided equally between the two parties. This is a unique arrangement, which apart from the monetary aspects also includes community responsibility for the maintenance of the road and the facilities. The arrangement is contractual - as between equal legal persons with similar rights and obligations before the law - and was not framed as co-management. The court ruling meant that CC Catac's net income related to tourism, which had exploded with the occupation of Pastoruri in 2001 , plummeted to a mere $10 \%$ comparing 2007 to 2008 . It has since been recovering and in 2011 it was at $65 \%$ compared to $2007^{7}$. Beyond the hard figures, the comuneros interviewed expressed deep frustration and a sense of historical continuity in the way that the court ruling effectively dispossessed them of economic and territorial rights.

The 1997 legal case concerning the legitimacy of the boundaries created by the park points to the complex legal arrangements surrounding the territories of the Andes. Different legislative frameworks can therefore be enacted in 


\section{8 / Rasmussen et al.}

the process, the park relying on the law of protected areas while the community relies on the law of comunidades campesinas, among others. Neither the park nor CC Catac has full title to the lands. In CC Catac, following the 2007 court ruling the community discovered that parts of the territories they believed to be theirs legally had been formally titled to the park, a move that constituted a claim to legal ownership. Such initiatives are met with anger and resistance within the community, which resents the symbolic enclosure entailed by this action. Legal titles matter not only in terms of spatial control but also as a token of the historical right to govern such spaces. The failure by the park to recognise the territorial integrity of CC Catac translates into distrust and the erosion of park legitimacy in other arenas.

The legitimacy of the park in CC Catac varies according to both time and place. In the same breath, comuneros can therefore both lament the reduced number of park rangers as well as denounce the park administration for abuse of funds and covert territorial dispossession. In short, the relationship between CC Catac and the Park is multi-stranded, but profoundly shaped by the historical conjuncture of territorial claims which undermines park legitimacy. Spatially, it is concentrated on the route to Pastoruri and the recently refashioned tourist facility in itself. Furthermore, important encounters between local livelihood and development priorities and park administration occur along the lines of productive infrastructures, informal mining and high-altitude pastures, all of which reveal the simultaneity of coercion and inclusion and thus the situatedness of park legitimacy.

Recently, Pastoruri has been the site of substantial investment in the Ruta del Cambio Climatico, an attempt by the park in cooperation with the municipality (but only to a limited extent the community) to rework the tourist experience from one of direct engagement with the now-depleted glacier to one of interpreting landscapes affected by climate change (Rasmussen 2018b). The central interface between the park and CC Catac is the legally binding contract, which was signed following the ruling on the Pastoruri case. In the renegotiations of the contract, CC Catac expressed a wish to claim a 100 percent share of the income generated by admission fees at the entrance at Carpa - something unacceptable to the park, which was in the process of implementing a different strategy regarding the relationship between the park and comunidades campesinas. Here we turn to the second case, that of CC Unidos Venceremos.

\section{Unidos Venceremos: the signing of an 'exemplary model' contract}

With approximately 400 families, CC Unidos Venceremos ("Together We Stand") extends over 931 ha, starting at an altitude of $3,300 \mathrm{~m}$ and stretching to the boundary of the national park. CC Unidos Venceremos was formally recognised by the state in 1977 (R. N 061-OAE/JAF-ORAMS-III-77) and holds titles to over 500 ha of land since 1981 (title number G-0039-61) (Osorio 2009; SICCAM 2016). Community livelihoods depend on a combination of small-scale, subsistence agriculture, floriculture, livestock rearing and, increasingly, on tourism-based enterprises such as the preparation and sale of food within the park's boundaries and in the restaurants dotted along the main road to Llanganuco Lake. Residents in the upper villages maintain livestock within the boundaries of the national park.

The Llanganuco sub-basin is situated at approximately 3,800 m above sea level. Nestled between Mounts Huascarán and Huandoy, it contains two of the park's most important tourism resources: the turquoise-coloured lakes called Chinancocha and Orconcocha. The checkpoint is a twenty-minute drive from Huashao, where many community leaders reside. The contested distribution of income and responsibility between comuneros working within the park's boundaries-initiated processes, that culminated in the signing of a contract between the leaders of CC Unidos Venceremos and the park, the first of its kind between a national park authority and a comunidad campesina in Peru. For the National Parks Service (SERNANP) in Lima, this institutional innovation has been a promising setup as they see the potential to export its architecture to other protected areas. Previously, prominent families and leaders of CC Unidos Venceremos sought to develop livelihood opportunities presented by the tourist trade in the Llanganuco sub-basin. Two privately owned vendor organisations had dominated the provision of food and boat excursions on Lake Chinancocha for almost twenty years. In 2012, when comuneros discovered that the community name was being used by vendor organisations to promote services to visitors, they blocked the entrance to the national park in protest, insisting that only 'a lucky few' were benefiting.

The weak relationship between the Park and the vendor organisations, together with the possibility of forging a more formalised arrangement using existing community institutions, facilitated the new arrangement. Even though to a much lesser extent than in CC Catac, the presence of livestock within the park nucleus represents a nuisance to park administration. Historically, members of the associations paid scant attention to requests by management to remove livestock from park grounds and to discontinue use of native queñual (Polylepis sp.) trees for construction. Once agreed, the contract's business terms show direct engagement with the community's internal statute and national tourism legislation ${ }^{8}$. The obligation to reduce the number of livestock was included in the contract, effectively coupling conservation outcomes to tourism economies (see terms of the contract below). Thus, using the institutions of the internal statute that delimited the economic pursuits of CC Unidos Venceremos and appealing to the use of legal frameworks by the same, the Park could leverage its authority by gradually formalising an otherwise weak arrangement. This held the promise of shaping local livelihoods in accordance with their conservation agenda.

The ambitions and vision of the communal leadership made CC Unidos Venceremos receptive to this type of contract, conveying a desire to create and exploit economic opportunities for community development. In recognition, then, of the 
weakness of its arrangements with vendor organisations, as well as the possibility that negotiating an agreement with CC Unidos Venceremos could promote compliance with conservation, the park negotiated the terms of the Rural Community Tourism project at consultation workshops in 2012. The usufruct rights of comuneros granted by the park were agreed in the five-year Contract of Tourist Services in Llanganuco sub basin - Parque Nacional Huascarán (2013), signed in July 2013. ${ }^{9}$

In exchange for the socio-economic benefits associated with the control of certain services ${ }^{10}$, the community pays 30 centavos $^{11}$ to the National Protected Areas Service (SERNANP) for every tourist who enters the park, and commits to supporting conservation efforts, including promising to remove 250 head of cattle, collect solid waste, assist with reforestation (i.e. plant one thousand seedlings of queñual per year for five years), maintain tourism infrastructure, and provide communal park rangers. The community was granted authority by the park to initiate tourist services in areas where some services already existed, with some room to negotiate their entry into new areas currently controlled by the Park, such as the official camping area. Areas like the visitor centre continue to be under the direct control of the Park.

Community leadership has taken control of distributing benefits and managing funds. This perceived surrender of control of the services at Llanganuco was an achievement and a source of pride and reputation for community leaders, as it meant that they could add this site to their pool of resources in a community where land was becoming increasingly scarce. The terms of the contract reflected the development plans for $\mathrm{CC}$ Unidos Venceremos, a key priority of which was the generation and administration of funds from their control of production services at recreation zones. They wished to be perceived as open to cooperating with authorities and focused on creating and negotiating mutually beneficial opportunities.

In theory, complying with the internal statute should ensure the fair distribution of work and funds to the comuneros most in need (Art. 20), and fulfil commitments to the Park. However, some park workers complained that work was being diverted from some members whose families had fallen out of favour with the leadership. While the business plan claimed to analyse the 'social participation' of the planned project, its account was limited to a gendered headcount of the numbers working in the park, with no instructions as to the mechanisms for ensuring fair distribution. ${ }^{12}$ The distribution to the más necesitados, the neediest, as stipulated in the statute, was proving highly political and dependent on the leaders in charge of deciding the rotating shift schedule. Further, the economic administration of the contract, in the absence of the park, has been contested: as communal coffers increased, accounting procedures became increasingly complex to manage and explain in meetings of hundreds of members, triggering concerns about spending and receipts. The administrative burden of implementing the contract was perhaps underestimated by both the park and the community, reflecting the unpredictable and ongoing socio-political process at work in conservation encounters.
The tourism contract partially increases the legitimacy of the Park in CC Unidos Venceremos through a community-based approach with demonstrable impacts on resource governance and livelihoods at the community-level. The Park's conservation agenda is first legitimised in the contractual alignment of conservation goals with community commitments. CC Unidos Venceremos thus remains in control of resource-governing institutions, in exchange for their commitment to carry out conservation activities. These arrangements depict the park as an ally to the community as the relationship changed from one dominated by a small number of self-interested families to (theoretically speaking) a fairer community-oriented, benefit-sharing arrangement. The park's legitimacy was further enhanced by its recognition of and engagement with the leadership's vision for community development, which coalesced with the park's broader agenda of creating economic opportunities with communities. However, the legitimacy of this arrangement is precarious because of internal community politics, whereby different fractions seek to secure control over the tourist revenues. Such dynamics are not only affected by internal political dynamics, but also by the extent to which the coupling of the tourism contract with conservation goals, such as removal of livestock and reforestation, continues to be at odds with livelihood pursuits at the local level. The park's legitimacy may become contested if the burden of responsibility for ordering activities in the park becomes too unwieldy for community leaders to manage alone. Thus, the successful outcome of the 'exemplary contract' depends on the robustness of the relations and material resources drawn together around tourism economies.

\section{Cruz de Mayo: a strategic alliance against a common} threat

CC Cruz de Mayo was formally recognized by the Peruvian state in 1976 (R. N $\mathrm{N}^{\circ}$ 027-OAE/JAF-ORAMS-III-76), and today the community consists of approximately 680 registered comuneros and 3700 residents, with the community holding formal land title to 4733 ha located between the eastern reaches of the city of Caraz and the western boundary of the Park (CEAS 2011). The direct role of the Park's landholdings in local livelihoods is more limited in the CC Cruz de Mayo case than in either the CC Catac or CC Unidos Venceremos contexts. This is due in part to the fact that most community households are located at elevations well below the park boundary, and livelihoods in this area are primarily agriculture-based. Thus, comuneros do not rely heavily on park landscapes for fodder; while livestock owned by comuneros do graze on park lands, herds are much smaller than in valleys further south where pastoralism is predominant. Nor has tourism developed as a major income source for CC Cruz de Mayo members, despite the fact that nearby park lands around Lake Parón (the largest lake in the Cordillera Blanca and the Park) have been designated as a priority zone for tourism development within park planning documents since 1990 (HNP 2003). The limited development of conventional tourism in the area, 


\section{0 / Rasmussen et al.}

its substantial scenic appeal notwithstanding, is attributable primarily to difficult access: Lake Parón is reached by a tortuous $32 \mathrm{~km}$ dirt track from Caraz that is not suitable for the buses often used to transport visitors to popular tourism sites like the Pastoruri Glacier and the Llanganuco basin. Moreover, while the mountains that surround Lake Parón draw a number of climbers each season, the lack of a major trekking route in the area significantly limits the adventure tourism market.

Yet while few local livelihoods depend directly on the park's territory, water from Lake Parón and other sources within the Park is a critical resource for local agrarian production, especially during the annual dry season when it buffers reduced stream flows and supports crucial irrigation (French 2018). This hydrologic dependence is a central aspect of the conjuncture that has connected the CC Cruz de Mayo community and the administration of the Park in shaping the management of park resources during the past decade. Specifically, after several decades of limited park staff presence in the areas of the Park adjacent to $\mathrm{CC}$ Cruz de Mayo territory, a resource conflict between local residents (including CC Cruz de Mayo, other local irrigators, and residents of Caraz) and the multinational corporation Duke Energy, who possessed rights to use water from Lake Parón for hydropower production, led to increased engagement from park authorities in the region. This conflict began to emerge in 2001, reached its highest level of intensity between 2008-2010, and remains latent but unresolved in 2017 (French 2018).

Direct involvement of Park staff in the Lake Parón conflict began as early as 2004 when, after several years of mounting community complaints regarding Duke Energy's management of the lake's outflows, park personnel evaluated the impacts of the company's practices on the lake's ecosystem. This evaluation reinforced reports from CC Cruz de Mayo members of negative impacts to the ecosystem linked to the energy company's management regime. Accordingly, the park requested greater cooperation from the company in supporting conservation objectives and the enforcement of park regulations. The negative impacts on the region's tourism sector of the 'inappropriate management' of Lake Parón's waters for hydropower had also been identified in the 2003 Management Plan (HNP 2003, 37).

Nevertheless, efforts by the Park and other state entities to reduce the impacts of Duke Energy's management regime had little effect on the company's practices, and in $2008 \mathrm{CC} \mathrm{Cruz}$ de Mayo comuneros, along with other local actors, seized the discharge infrastructure and evicted Duke Energy from the park's territory (Carey et al. 2012). Since this eviction, park personnel - while never condoning the infrastructure seizure - have played an important role in ongoing conflict-resolution efforts. For example, park-affiliated legal counsel worked to annul an 'erroneous' land title to 540 ha of park territory, including Lake Parón and its surroundings, that originally had been registered to the state energy company Electroperú in 1994 before being inherited by Duke through privatisation, when the transfer became a key point of dissatisfaction for local residents (French 2016). The annulment of this title and the return of the 540 ha to the Park were finally achieved in early 2010 as a precondition for the local coalition's participation in the multi-sectorial management of Lake Parón.

After Lake Parón and its surroundings had been returned to the Park in 2010, its administration led an effort to develop a site plan and linked tourism development and management strategy for the Parón basin with a range of local actors, including the leadership of CC Cruz de Mayo as well as the local ASAAM and CUP (HNP 2011). The process of developing this site plan involved several workshops that provided fora for the discussion of diverse visions and priorities for development and conservation in the zone, and the resulting document describes in detail an expanded tourism sector with an array of services to be provided by and concessioned to local actors (HNP 2011). Facing continued difficulties in accessing the Parón basin and an ongoing lack of tourist demand, however, this plan remains largely unimplemented while local actors continue to pursue predominantly agrarian livelihoods.

Despite the challenges to the development of a thriving tourism sector in the Parón basin, the CC Cruz de Mayo community and Park authorities have found the stewardship of Lake Parón and its surroundings to be a key point of alliance. In addition to providing support in preventing impacts from hydropower regulation, CC Cruz de Mayo sees the park as a strategic ally in the defence of its territory from mining firms, which in recent years have sought entry to community-controlled territory on the border of the Park. We thus conclude that, after several decades of minimal interaction and recognition, in the current conjuncture the legitimacy of the park is recognised and supported by the CC Cruz de Mayo community. This outcome is a result of emerging synergies between park policies and local goals of territorial and resource control. Moreover, so long as the community position on defence of its resources from mining and hydropower firms is not reversed, the park's authority and legitimacy in the CC Cruz de Mayo territory is likely to increase further through shared stewardship values and ongoing efforts to install a permanent park presence in the region, and to give tourism a greater role in local livelihoods.

\section{CONCLUSION: CONSERVATION CONJUNCTURES}

We have argued that legitimacy is conjunctural and may often be opportunistic. Our three case studies show how larger-scale processes become enmeshed in local affairs. Within this complexity of arrangements and the struggle to legitimate them, we therefore find that people generally accept the principles of conservation as long as they do not run counter to ideas about who may control resources. We have emphasised the negotiations evolving around the creation of strategic alliances or antagonisms and suggested three domains which together reveal the situatedness of legitimacy in conservation encounters: 1) the materiality of the resource, 2) the historical conditions of resource control, and 3) the concrete modalities of governance. By way of conclusion we attend to each of these below. 
Resource Materiality: The nature of the resources, their materiality and the way in which social relations are drawn together around them are key factors shaping conservation encounters. There is great variation between our cases, not only across space, but also through time. For the communities, the park matters only at certain moments. In the case of CC Cruz de Mayo, for thirty years the creation of the park had little impact on local livelihoods and understanding of the landscape. But as real and imagined water scarcities and ecological impacts became pertinent, the political economy of energy provision rearticulated the relationship, creating a tacit alliance between park and people. In the cases of CC Catac and CC Unidos Venceremos, the relationship has been shaped by the shifting conjunctures of tourism. People seek means to control the conditions of their existence. Contracts between park and communities can be valued if they are seen as enhancing livelihood opportunities while keeping control of development within the community. The different communities prioritise their engagements with the park administration accordingly. The level of compliance is therefore connected to the relationship between the contracts and the wider influence on livelihoods.

Historical conditions: Resource control colonises territories in particular ways. The park in itself was the outcome of a particular historical conjuncture that inscribed it upon a landscape of territorial struggles. Its territoriality continues to be highly fragmented. In places such as CC Catac, where local people historically inhabited the high altitudes - using the pastures as primary sites of rural production and imagining the territories as constitutive of the community - the relationship to the park has been strained by the apparent continuity of territorial domination across time. While tourism has the capacity of generating substantial off-farm income, its way of making use of the landscape and of articulating peasant economies to the market is quite different. Recent conservation conjunctures have created conditions in which more subtle and indirect forms of territorialisation of resource control become possible. The legalistic framing of the park-community relationship through contracts establishes a narrow relation of accountability that potentially enables the park administration to expand its control over local resource use.

The ongoing legal disputes in CC Catac, the signing of contracts in CC Unidos Venceremos, and the ongoing conflict around the water of Lake Parón in CC Cruz de Mayo all suggest the strategic usage of different legal languages and institutional forms. Accustomed to these through a long history of territorial struggles, the comunidades campesinas are no strangers to Peru's legal and bureaucratic diversity. In all places, comunidades campesinas show adeptness in their engagements with relevant institutional frameworks. The legal frameworks that shape the relationship between park and people are conjunctural: at different times, contrasting laws and institutions are enacted and embraced so as to back up claims based on territorial rights, resource use, and income sharing. The shifting legitimacy of legal claims therefore translates into the current contestations as well as collaborations over resources and development. Claims to legitimacy are therefore folded into the historically conditioned interactions.

Modalities of governance: Conservation conjunctures are historically conditioned sedimentations that continuously shape the park-people relationship. We therefore do not see archetypes of conservation, but rather the temporary emergence of modalities of governance and claims to legitimacy that pertain to these, existing partially and simultaneously in the same space. Thus, legal dispossession of historical territories, symbolic enclosure through zoning and policing, and community claims to compensation are simultaneous to community-based conservation initiatives, strict contractual relations, strategic alliances against external pressure and everyday interactions between comuneros, park rangers and staff from the central office. Communities sharing territories and resources with protected areas articulate their claims in specific and historically grounded ways.

The cases reveal how the park has tried, both successfully and unsuccessfully, to manage and interact with this diversity, and the distinct challenges posed by each of these cases. We reiterate that the park has to negotiate its presence with more than fifty communities that all have their particular histories. Only in sites and moments of particular interest in resource landscapes does the question of legitimacy become pertinent. The variety of strategic alliances with fractions of the communities reveals that local forms of authority matter. The legitimacy of the park for the surrounding communities therefore hinges upon its ability and willingness to recognise and cultivate the links between protected but shared landscapes and local livelihoods and identities.

A national park is a territorial claim with distinct meaning and significance for different social groups: where some see conserved landscapes to be enjoyed through recreation, others see the externally imposed enclosure of resources vital to livelihoods. While some national parks are relative fortresses, others are mere legal constructions, enshrined in documents that have no bearing on the ground. However, many national parks do not neatly fit either the fortress or paper-park archetype but instead articulate different modalities of governance within the same institutional structure. This also has policy implications: the simultaneity of such modalities of governance within a single park may be articulated differently in different parts of its territory, depending, among other factors, on the legitimacy which is conditioned by the nature of the resource, the historical relationship and the concrete modalities of governance. Recognising the particularity and robustness of local institutions, park administrations negotiate legitimacy through particular interactions with each of them. Conservation conjunctures are thus also conditioned by everyday interactions between stakeholders and the park officials, who do not necessarily see themselves as imposing a particular kind of territorial or discursive order, but rather facilitating a social relationship. This relational dimension to the conservation conjunctures reveals that there is room for choices and actions of communities in their relationship - conflictive as well as conciliatory - and, consequently, that local livelihoods can be structured and negotiated by both parties. 
12 / Rasmussen et al.

\section{NOTES}

1. More than 6.000 comunidades campesinas exists in Peru, most of them in the Andean highlands. As such, they can act as legal persons with obligations and rights enshrined in the shifting constitutions since 1920. While the fundamental logic of the community is territorial with an emphasis on rural production, state recognition as comunidad campesina does not equal territorial rights.

2. Promulgated on June 24, 1969, the agrarian reform of President Velasco (1968-1975) fundamentally changed patterns of land tenure (Decreto Ley No. 17716). The reform had been some time underway, and the failed 1964 agrarian reform carried out by President Belaúnde was part of the background to the military coup led by Velasco. Expropriating and dividing large expanses of rural property, it was a response to the increasing concentration of land ownership in the coastal and Andean regions. While comunidades campesinas (institutionalised as comunidades indigenas since the 1920 Constitution under President Leguía) were not a new invention of the reform, the agrarian reform profoundly changed social relations in rural areas (Mayer 2009; Lowenthal 1983). Although the outcomes of Velasco's reform were ambiguous, the reform dismantled large estates and enabled the proliferation of comunidades campesinas (Del Castillo 1992, 1997).

3. Active industrial-scale mining does exist within one valley of the park (Quebrada Honda) due to the fact that the residents of this territory (the Comunidad Campesina of Vicos) obtained formal title to the lands now within the park's boundary prior to the formation of the park, creating a private inholding. As these lands are officially private property, the land owners have the right to permit mining and restrict park service staff from monitoring or even entering this inholding. The protected area has otherwise served a critical role in conserving its territory from the mining industry that has seen prodigious growth in the central Andean highlands over recent decades (Bebbington and Bury 2009). As mining concessions have been established throughout the region, the park has protected approximately 15 percent of Ancash's territory from this development. The park's position on hydropower-related development has been less clear historically, with the establishment of regulating infrastructure on some highland lakes. Thus, we see how in a sense, the park serves as a "fortress" strictly prohibiting some land uses, while compromising its formal regulations with regards to others.

4. Article 31 reads: 'The administration of the protected area will give priority attention to ensure traditional uses and the life-systems of the native comunidades and comunidades campesinas living in the Natural Protected Areas and their environments, paying respect to their self-determination to the extent that such uses are compatible with the aim of the areas. The state promotes the participation of these communities in the establishment and achievement of the aims and objective of the Natural Protected Areas' (our translation).

5. Sources: NHP 2011, p. 222-223; https://diariocorreo.pe/ edicion/chimbote/ancash-parque-nacional-huascaran-recibiomas-de-180-mil-visitantes-en-2014-599209/; http://www. ancashnoticias.com/2016/12/3306/; http://www.sernanp.gob. pe/turismo-en-anp; https://www.mincetur.gob.pe/wp-content/ uploads/documentos/turismo/estadisticas/Setiembre_2016.pdf. Accessed on April 11, 2017.
6. The organisations are 'Asociación de Prestadores de Caballos 'Los Andes de Pastoruri", Asociación de Vendedores de Golosinas y Artesanías 'El Nevado", Comité de Vendedores 'Las Puyas", and Comité de Vendedores de Alimentos de Pastoruri.

7. According to Serafín Osorio (Osorio B. 2013), who has meticulously worked his way through the accounts of CC Catac, in 2007 net income from Pastoruri was 101.257 nuevos soles, while in 2008 it was $9.597,50 \mathrm{~N} / \mathrm{S}$. By 2011, it was $62.492 \mathrm{~N} / \mathrm{S}$. (p. 258). In 2016, admission fees from 56.980 visitors were to be distributed equally between CC Catac and the Park.

8. Under the contract, Articles 10, 118 and 122 of the internal statute are shown to adhere to national legislation that promotes the formalisation and development of small and medium-sized enterprise and access to employment (Decreto Legislativo $\mathrm{N}^{\circ}$ 1086, Decreto Supremo Nº07-2008-TR, Decreto Supremo N ${ }^{\circ}$ 008-2008-TR). For instance, Article 10 states the community's commitment "to organise and develop business activity, through the generation of communal production units of goods and services in order to guarantee the wellbeing of all members", while Article 118 states that CC Unidos Venceremos will "promote tourist activity for the economic development of the Community" (Internal Statute of CC Unidos Venceremos).

9. The plan was compiled by three graduates with degrees in tourism, business administration, and engineering respectively.

10. Workers earn an hourly wage and the money from the sale of products and services contributes to the community fund

11. This amount would increase by 10 centavos per year, reaching 60 centavos by the fifth year.

12. In total, 70 people were working in the park, 45 women and 25 men, with women dominating in the provision of food and drink and sale of crafts, and men controlling boat excursions.

\section{Legislative frameworks}

R. N ${ }^{\circ}$ 061-OAE/JAF-ORAMS-III-77 - Recognition of CC Unidos Venceremos

R. N ${ }^{\circ}$ 027-OAE/JAF-ORAMS-III-76 - Recognition of CC Cruz de Mayo

Resolución Suprema S/N, February 18, 1946, ratified by R.S. no. 045, June 24, 1957 - Recognition of CC Catac

Decreto Ley No. 17716 - Agrarian Reform

Decreto Supremo No. 0622-75-AG - Creation of Huascarán

National Park

Ley 24656, Ley General de Comunidades Campesinas - Law of Comunidades Campesinas

Ley 26834, Ley de Areas Naturales Protegidas - Law of Protected Areas

Decreto Supremo no. 038-2001-AG - Regulations to Ley de Areas Naturales Protegidas

Decreto Legislativo N ${ }^{\circ} 1086$,

Decreto Supremo N ${ }^{\circ}$ 007-2008-TR,

Decreto Supremo N008-2008-TR.

\section{REFERENCES}

Adams, W. and J. Hutton. 2007. People, parks and poverty: political ecology and biodiversity conservation. Conservation and Society 5(2): 147-183. 
Asher, K. and D. Ojeda. 2009. Producing nature and making the state: Ordenamiento territorial in the Pacific lowlands of Colombia. Geoforum 40(3): 292-302.

Baral, N. and M.J. Stern. 2010. Looking back and looking ahead: local empowerment and governance in the Annapurna Conservation Area, Nepal. Environmental Conservation 37(1): 54-63.

Barker, M.L. 1980. National parks, conservation, and agrarian reform in Peru. Geographical Review 70(1): 1-18.

Bebbington, A.J. 2000. Reencountering development: livelihood transitions and place transformations in the Andes. Annals of the Association of American Geographers 90(3): 495-520.

Bebbington, A.J. and J.T. Bury. 2009. Institutional challenges for mining and sustainability in Peru. Proceedings of the National Academy of Sciences 106(41): 17296-17301.

Blackman, A., A. Pfaff, and J. Robalino. 2015. Paper park performance: Mexico's natural protected areas in the 1990s. Global Environmental Change 31: 50-61.

Brockington, D. 2002. Fortress conservation: the preservation of the Mkomazi Game Reserve, Tanzania: Indiana University Press.

Brockington, D. and K. Scholfield. 2010. The conservationist mode of production and conservation NGOs in sub-Saharan Africa. Antipode 42(3): 551-575.

Bury, J.T., B.G. Mark, J.M. McKenzie, A. French, M. Baraer, K. In-Huh, M.A. Zapata Luyo, et al. 2011. Glacier recession and human vulnerability in the Yanamarey watershed of the Cordillera Blanca, Peru. Climatic Change 105(1-2): 179-206.

Carey, M. 2010. In the shadow of melting glaciers: climate change and Andean society. Oxford: Oxford University Press.

Carey, M., A. French, and E. O'Brien. 2012. Unintended effects of technology on climate change adaptation: an historical analysis of water conflicts below Andean glaciers. Journal of Historical Geography 38(2): 181-191.

CEAS. 2011. La Comunidad Campesina Cruz de Mayo: Una comunidad que defiende y promueve la Vida. Lima: Comisión Episcopal de Acción Social.

Cleaver, F., and J. De Koning. 2015. Furthering critical institutionalism. International Journal of the Commons 9(1): 1-18.

Colfer, C. and J. Pierce. 2011. Marginalized forest peoples' perceptions of the legitimacy of governance: an exploration. World Development 39(12): 2147-2164.

Connelly, S., T. Richardson, and T. Miles. 2006. Situated legitimacy: deliberative arenas and the new rural governance. Journal of Rural Studies 22(3): 267-277.

Del Castillo, L. 1992. ¿Tienen futuro las comunidades campesinas? Debate agrario 14: 17-22.

Del Castillo, L. 1997. Propiedad rural, titulación de tierras y propiedad comunal. Debate agrario 26: 59-79.

Diez, A. (ed.) 2012. Tensiones y transformaciones en comunidades campesinas. Lima: Centro de Investigaciones Sociológicas, Económicas, Políticas y Antropológicas (CISEPA).

Ekers, M, A. Loftus, and G. Mann. 2009. Gramsci lives! Geoforum 40(3): 287-291.

Fariss, B. L. 2007. Finding common ground: conservation, development and indigenous livelihoods in the Huascarán Biosphere Reserve, Peru. Ph.D. thesis. The University of North Carolina at Chapel Hill, North Carolina, USA.

French, A. 2016. El desborde del conflicto por la Laguna Parón. In: El estado frente a los conflictos por el agua (eds. Urteaga, P., A. Guevara, and A. Verona). Lima: Fondo Editorial de la Pontificia Universidad Católica del Perú.

French, A. 2018. (forthcoming). Webs and flows: socionatural networks and the matter of nature at Peru's Lake Parón. Annals of the American Association of Geographers.
Goldman, M. 2003. Partitioned nature, privileged knowledge: community-based conservation in Tanzania. Development and Change 34(5): 833-862.

Grötzbach, E. 2003. Tourism in the Cordillera Blanca region, Peru. Revista Geográfica 133: 53-72.

HNP (Huascarán National Park). 2003. Plan Maestro 2003-2007. Informe No 41-2004-SEV. Huaraz: Parque Nacional Huascarán.

HNP (Huascarán National Park). 2011. Plan Mast0072o 2010-2015. Huaraz: Parque Nacional Huascarán.

Jeffrey, A., F. McConnell, and A. Wilson. 2015. Understanding legitimacy: perspectives from anomalous geopolitical spaces. Geoforum 66: 177-183.

Leino, H. and J. Peltomaa. 2012. Situated knowledge-situated legitimacy: consequences of citizen participation in local environmental governance. Policy and Society 31(2): 159-168.

Li, T.M. 2007. The will to improve: governmentality, development, and the practice of politics. Durham, NC: Duke University Press.

Li, T.M. 2014. Land's end: capitalist relations on an indigenous frontier. Durham, NC: Duke University Press.

Li, T.M. 2016. Governing rural Indonesia: convergence on the project system. Critical Policy Studies 10(1): 79-94.

Lipton, J.K. 2014. Lasting legacies: conservation and communities at Huascaran National Park, Peru. Society \& Natural Resources 27(8): 820-833.

Lowenthal, A.F. 1983. Introduction. In: The Peruvian experiment reconsidered (eds. McClintock, C. and A. Lowenthal.). Princeton, NJ: Princeton University Press.

Lund, C. 2016. Rule and rupture: state formation through the production of property and citizenship. Development and Change 47(6): 1199-1228.

Mayer, E. 2009. Ugly stories of the Peruvian agrarian reform. Durham, NC: Duke University Press.

McCall, M.K. 2016. Beyond "landscape" in REDD+: the imperative for "territory". World Development 85: 58-72.

Mitchell, T. 2002. Rule of experts: Egypt, techno-politics, modernity. Berkeley: University of California Press.

Moore, S.F. 2000. Law as process: an anthropological approach. Münster: LIT Verlag.

Moore, S.F. 2005. Comparisons: possible and impossible. Annual Review of Anthropology 34(1): 1-11.

Mosse, D. 2004. Is good policy unimplementable? Reflections on the ethnography of aid policy and practice. Development and Change 35 (4): 639-671.

Nelson, F. and A. Agrawal. 2008. Patronage or participation? communitybased natural resource management reform in Sub-Saharan Africa. Development and Change 39(4): 557-585.

Osorio, B.S. 2009. Las Comunidades Campesinas en la Región Ancash. Lima: Grupo Allpa.

Osorio B.S. 2013. Acción colectiva y conflicto de intereses. El caso de la Comunidad Campesina de Cátac (Recuay - Ancash). Ph.D. thesis. Escuela de Posgrado en Antropología, Pontificia Universidad Católica del Perú, Peru.

Paloniemi, R. and A. Vainio. 2011. Legitimacy and empowerment: combining two conceptual approaches for explaining forest owners' willingness to cooperate in nature conservation. Journal of Integrative Environmental Sciences 8(2): 123-138.

Raimondi, A. 2006 [1873]. El Departamento de Ancachs. Colección de estudios geologicos y mineros para la obra "El Perú", Vol. II. (ed. Villacorta Ostolaza, L.F.). Lima: Fondo Editorial Universidad Nacional Mayor de San Marcos, Asociación Educacional Antonio Raimondi, Antamina and COFIDE.

Rantala, S. and L.A. German. 2013. Exploring village governance processes behind community-based forest management: legitimacy and coercion in the Usambara Mountains of Tanzania. International Forestry Review 15(3): 355-367. 


\section{4 / Rasmussen et al.}

Rasmussen, M.B. 2015. Andean waterways: resource politics in the Peruvian highlands. Seattle, WA: University of Washington Press.

Rasmussen, M.B. 2016. Water futures: contention in the construction of productive infrastructure in the Peruvian highlands. Anthropologica 58(2): 211-226.

Rasmussen, M.B. 2018a. Paper works: contested resource histories in Peru's Huascarán National Park. World development 101: 429-440.

Rasmussen, M.B. 2018b (forthcoming). Rewriting conservation landscapes: protected areas and glacial retreat in the high Andes. Regional Environmental Change.

SICCAM (Sistema de Información de Comunidades Campesinas del Perú). 2016. Directorio 2016. Comunidades campesinas del Perú. Lima: Instituto del Bien Común; Centro Peruano de Estudios Sociales (CEPES).

Sikor, T. and C. Lund. 2009. Access and property: a question of power and authority. Development and Change 40(1): 1-22.

Stern, M.J. and K.J. Coleman. 2015. The multidimensionality of trust: applications in collaborative natural resource management. Society \& Natural Resources 28(2): 117-132.

Thorp, R. and G. Bertram. 1978. Peru, 1890-1977: growth and policy in an open economy. New York: Columbia University Press.
Torres, M. 1996. Participatory planning for ecotourism development in the Peruvian highlands. In: The ecotourism equation: measuring the impacts (ed. Malek-Zadeh, E.). New Haven, CN: Yale School of Forestry and Environmental Studies Bulletin Series.

Tsing, A.L. 2005. Friction. an ethnography of global connection. Princeton and Oxford: Princeton University Press.

von Benda-Beckmann, K. 1981. Forum shopping and shopping forums: dispute processing in a Minangkabau village in West Sumatra. The Journal of Legal Pluralism and Unofficial Law 13(19): 117-159.

Weber, M. 1968. Economy and society: an outline of interpretive sociology. New York: Bedminster Press.

West, P., J. Igoe, and D. Brockington. 2006. Parks and peoples: the social impact of protected areas. Annual Review of Anthropology 35(1): 251-277.

Yeh, E.T. 2012. Transnational environmentalism and entanglements of sovereignty: the tiger campaign across the Himalayas. Political Geography 31(7): 408-418.

Young, K.R. and L.O. Rodriguez. 2006. Development of Peru's protected-area system: historical continuity of conservation goals. In: Globalization and new geographies of conservation (ed. Zimmerer, K.S.). Chicago, IL: University of Chicago Press. 